\title{
'Halal' Fiction and The Politics of Faith-Driven Praxis: A Critical Reading of Leila Aboulela's The Translator
}

\author{
Mamadou Abdou Babou Ngom, Ph.D.
}

English Department, Faculty of the Humanities, Cheikh Anta Diop University of Dakar, Senegal, West Africa

\begin{abstract}
Using Leila Aboulela's signal novel, The Translator, as a stepping-stone, I set out in this research paper to address 'Halal fiction' as an articulation of a faith-driven praxis, whose bearing on matters such as courtship between partners of different faiths (that is, a Muslim woman and a non-Muslim man) cum identity construction against a background of immigration, bears testimony. The paper argues that the overarching hallmark of faith that characterizes Halal fiction, also known as Islamic fiction, means that religious morality permeates every facet of life in it. Islamic fiction, it bears stressing, portrays a set of characters imbued with a strong sense of religious etiquette thanks to which they foster all guns blazing love and friendship while eschewing courses of action that fan the flames of hatred. I posit that Islamic fiction is a kind of standard bearer of the humanness of Muslim faith in Western societies where, oftentimes, fear and rejection of adherents of Muslim faith feed on intolerance as well as phony homogenizing claims of cultural supremacy. Deep-seated belief in Islam, so the paper contends, is not incommensurate by any means with harmonious living amongst folks of different cultural and religious backgrounds.
\end{abstract}

Keywords- halal fiction, faith, love, praxis, secularism, attachment, injury.

Leila Aboulela's consciousness about the acute need to bring to the fore the authenticity of Muslim faith put her on the map as one of the most prominent voices of Islamic fiction. Part Egyptian, part Sudanese, she was born in 1964 in Khartoum. This novelist of international renown left Egypt at a young age and went to settle in Sudan along with her parents, where she attended school and did part of her higher education. Leila Aboulela graduated from the London School of Economics with a Master's degree in Statistics. Despite her scientific bend, she displays artistic mastery and an exquisite felicity of style in her fictional opus. Since the inception of her literary career in the early 1990s, she has authored five novels on top of two collections of short stories, to wit, Coloured Lights and Elsewhere, Home. The Translator (1999), Minaret (2005), Lyrics Alley (2011), the Kindness of Enemies (2015), and Bird Summons (2019) resonate with Islamic faith and morality. She has some literary prizes cum awards conferred upon her in recognition of her invaluable contribution to literature, e.g., the Caine Prize for African Writing, the Fiction Winner of the Scottish Book Award, the Saltire Fiction Book of the Year Award. Leila

ISSN: $2456-7620$
Aboulela has been living in Aberdeen, Scotland, for a good many years now.

In this investigation project, I set out to get to grips with 'Halal fiction' as a praxis of life, and flag up its significance to love and identity construction against a background of immigration. Prior to coming to the nittygritty of the analysis, it would be wise from a scientific perspective to lay the spadework through a dissection of the rationale behind 'Halal fiction'. The critical attention received by this sub-genre of literature has ramped up over the past twenty or so years. The Oxford Advanced Learner's Dictionary (International Student's Edition) defines the adjective 'halal' as follows: "(of meat) from an animal that has been killed according to Muslim law." This definition, albeit cursory due to its limitation to food product, points to 'permissibility' in light of Islamic tenets. Conversely, Khan and Haleem's gloss gives us a better understanding of the word:

The word Halal comes originally from Arabic language meaning: allowable, acceptable, permitted, and/or permissible. The concept of Halal is not only related to 
food or food products (as most people will expect or think), but it goes beyond food to cover all the aspects of a Muslim person life (male or female). (33)

In light of the foregoing, the tag 'halal' applies to anything that is in synch with the requirements of Sharia law. In a move meant to be eclectically comprehensive with regards to the meaning of Halal, Khan and Haleem cites The Department of Standards Malaysia, whose perception of Halal refers to "things or action which are permitted or legal in Islam, which conveys basic meaning and defines the standards of acceptability in accordance to Sharia obligations" (33). 'Halal fiction' describes any fictional work written by Muslims with an eye to adhering to and upholding Islamic teachings. Strangely enough, Islamic fiction, in TalalAbass' estimation, cropped up against the backdrop of a huge blowback against Muslims the world over in the aftermath of Ayatollah Khomeini's fatwa on Salman Rushdie for his The Satanic Verses, and the 9/11 attacks, thereby causing them to circle the wagon (431). Even though the Muslim immigrants are diverse in terms of ethnicity and cultural ethos, 'faith' is a signifier of identity around which they are united, not so much out of a refusal to integrate into the host society but in the spirit of clinging onto authenticity. The etymology of the word "faith" speaks volumes about its sacredness: "Faith" is from the Greek word (pistis) and means, "firm persuasion, the conviction which is based upon hearing not upon sight, or knowledge; a firmly relying confidence in what we hear from God in His word' (Rolley 8). The blind confidence in God that hallmarks faith means that it is devoid of rationality. Yet faith and reason have this much in common: they "are both sources of authority upon which belief can rest" (Jones 74). The following is what marks faith off from reason:

Reason generally is understood as the principles for a methodological inquiry, whether intellectual, moral, aesthetic, or religious. Thus it is not simply the rules of logical inference or the embodied wisdom of a tradition or authority. [...] faith, on the other hand, involves a stance toward some claim that is not, at least presently, demonstrable by reason. Thus faith is a kind of attitude of trust or assent. As such, it is ordinarily understood to involve an act of will or a commitment of the part of the believer. Religious faith involves a belief that makes some kind of either an implicit or explicit reference to a transcendent source. (Jones 74)
Islamic writing is driven by faith. Its subject-matter over the past thirty or so years has been a reflection of a stubborn pushback against stigmatization of Muslims, not least Muslim migrants living in Europe or the US. At the same time, 'Halal fiction' flags up the hassles attendant upon migrants living in a land where Judeo-Christian faith is the mainstream. Arguably, Islamic fiction is a humanism as it seeks to erase cultural and geographical boundaries to foreground the commonality of mankind. What Martha Nussbaum calls 'narrative imagination' is inscribed in the politics of 'Halal fiction' writ large. She explains that,

This [narrative imagination] means the ability to think what it might be like to be in the shoes of someone different from oneself; to be an intelligent reader of that person's story; and to understand the emotions and wishes and desires that someone so placed might have, including the many ways in which social circumstances shape emotions and wishes and desires. (44)

Being a practicing Muslim in, say Europe, may expose you to criticism of self-isolation from your host country. Witness how British Muslims were blasted simply for registering and voicing in no uncertain terms their anger at Salman Rushdie over what they perceived as a blasphemous book against Islam and its Prophet:

It is common knowledge that the Rushdie
affair precipitated a sense of political crisis
in Britain. Large numbers of Muslims
publicly expressed their anger at the
publication of the Satanic Verses,
demonstrated in London, petitioned Penguin
Books to withdraw the book, and then the
government to ban it. The government
rejected the call for banning and warned
Muslims not to isolate themselves from their
host society. (Assad 239)

In the same breath, Talal Abbas is puzzled over the British government reaction. He critiques in thinly veiled words a perceived double standard, asking dryly "Why were these statements widely applauded by the liberal middle classes, whose pronouncements both before and after the government's intervention repeatedly denounced 'Muslim violence"" (239). From Assad's perspective, the tag 'Muslim violence' did not hold water as no demonstrators were arrested for causing mayhem. The anthropologist is at pains to mention "the innumerable angry demonstrations through the streets of London before by antiracists and fascists, by feminists and gays, by abortion rights activists, trade unionists and students." Despite 
"scuffles" breaking out "between demonstrators and police [...] in which injuries were sustained and arrests made," organizers did not get accused of stirring up violence (Assad 232). As for Geoffrey Nash, he laments the perception of Muslim communities in Europe as nonentities, whose religion is, so to speak, a throwback to medieval time (9). He posits that Muslims are on the receiving of what he terms a "Kulturkampf", the aim of which is to stamp out the supposed threat that Islam poses to Western values (9). He elaborates upon his point, arguing that the Kulturkampf against Islam is nothing short of an "articulation of the binary of ourselves and the Other, asserting the pre-eminence of a secular self that is culturally and politically hegemonic" (9). Indeed, it would not be thick to construe 'Halal writing' as a kind of writing back (to paraphrase Bill Ashcroft) to Western secularists ${ }^{1}$

1The origins of the term "secularism" stretch back to the nineteenth-century, with George Jacob Holyoake being its brainchild (Cliteur 64). The concept is a worldview or ideology that seeks to, if not stamp out, or at least, curtail the intrusion of 'Religion' in public life. According to Paul Cliteur, Holyoake coined "Secularism" so as to register his rebuttal of "atheism" which did not go down well with the populace: "He did this [the coinage of the term] because he was convinced that 'atheism' was in bad repute. He defined secularism as concern with the problems of this world (64). Holyoake adumbrates the tenets of "secularism" as follows: "(1) Secularism maintains the sufficiency of Secular reason for guidance in human duties. (2) The adequacy of the Utilitarian rule which makes the good of others, the law of duty. (3) That the duty nearest at hand and most reliable in results is the use of material means, tempered by human sympathy for the attainment of social improvement. (4) The sinlessness of well-informed sincerity. (5) That the sign and condition of such sincerity are -Freethought- expository speechthe practice of personal conviction within the limits of neither outraging nor harming others" Qtd. in Cliteur 64). In light of the foregoing, religious activities cannot bring about in any shape or form betterment in the lives of people. In the eyes of secularists, materialism overrides faith. The subjectivity of "faith" means that it can only play second fiddle to state institutions which are driven by Enlightenment thinking. In a powerful paper, Erin K. Wilson appositely notes that, in spite of its Western roots, Secularism does not make up a homogenous grouping (1079). That said, it has 'certain 'family resemblances' that characterize ideological forms of secularism across their different manifestations" (1079). A key commonality of the different strands of secularism the world over is the construction of religion as being within the realm of the private, and, accordingly, subservient to the state (1079). This warped perception of religion is a sheer disregard for the moral dimension that religion is supposed to bring to our daily lives, a point that top-flight anthropologist Talal Assad broaches inter alia, in his signal book, Formations of the Secular: Christianity, Islam, Modernity. From the get-go, Assad makes a key distinction between 'Secular' and 'Secularism', dubbing the former "an epistemic category" and the latter "a political doctrine" (1). Despite the brand of irrationality and intolerance stuck on religion by atheists or secularists -"It has been regarded by others with alarm as a symptom of irrationality and intolerance in everyday life"- the reach of religion is going ISSN: 2456-7620 whose jaundiced view of Islam goes a long to fanning the flames of white animus against Muslims both in Europe and the United States. Geoffrey Nash's perspective captures the deep-seated sense of Muslims' victimization as a result of the misconstruction of their religious identity:

In the west Muslims as a group are stigmatized for cultural backwardness and religious fanaticism. Outmoded stereotypes emphasize religious and cultural separatism/antagonisms. Increasing identification by religion has been imposed on Muslims by a variety of factors including political, societal, and media pressure, cultural chauvinism, and Muslim's own need for self-definition. (9)

Pride in Muslim identity and a clear-cut display of an aesthetic that attempts to bridge the cultural and religious divides are inscribed in 'Halal writing'. A leading figure in Islamic fiction, Leila Aboulela is fully aware of Muslims' positioning as fair game for stigmatization in the Western world writ large. Notwithstanding, her fictional opus is tinged with an obdurate concern to enact the possibility of practicing Muslim faith in a secular, nay anti-Islam environment. She acknowledges, nevertheless, that the hassles inherent in the task of foregrounding the humanism of Islam can be disheartening:
I want to write about the faith, but it's so difficult to talk about it like this when everyone else is talking about the political aspects. I'm concerned that Islam has not just been politicized but that it's becoming an identity. This is like turning religion into a football match, it's a distraction from the

increasingly significant. This, Assad says, is nothing if not a counterblast to any prediction that religion would vanish off the face of the earth with the advent of modernity. Religion is here to say as people view it as a kind of moral compass capable of humanizing a trifle secular institutions : "The contemporary salience of religious movements around the world, and the torrent of commentary on them by scholars and journalists, have made it plain that religion is by no means disappearing in the modern world. The "resurgence of religion" has been welcomed by many as a means of supplying what they see as needed moral dimension to secular politics and environmental politics" (1). It is common knowledge that many a secular country around the globe creaks under the weight of such ills as corruption, malfeasance, xenophobia-you name it. By the same token, there is no denying that the teachings of religions, not least the revealed ones, unreservedly put a proscription on immorality and wrongdoing. While shying away from advocating religious governments across the globe, I posit that secular institutions could do worse than tap into sort of the likes and dislikes of religions as it would help bring a measure a humanity of them for the benefit of mankind. 
real thing. (Qtd. in Akbar in The

Independent newspaper)

The emphatically pervasive display of Muslim identity in The Translator encapsulates a conception of an Islamic faith that feeds on conservatism interwoven with openness to diversity. To put it differently, it is a brand of conservatism that does not bear the unconscionable hallmark of exclusion driven by cultural supremacy. Rather, it betokens a philosophy of religion that blends morality into across the board tolerance. Wail S. Hassan's submission that "Islamic identity [...] takes precedence over cultural, ethnic, and national identities, and in fact renders them irrelevant" (194) is a measure of humanist universal edge to Islamic writing. This mindset fits into what high-profile scholar SabbaMahmood calls "Islamic Revival or Awakening" upon which she elaborates as follows: "'Islamic Revival or Awakening" is a term that refers not only to the activities of state-oriented political groups but more broadly to a religious ethos or sensitivity that has developed within contemporary Muslim societies' (3). The prominence of Halal fiction over the past two decades has given rise to an upsurge of interest in Islamic studies. Knowing about Islam provides a window into the philosophy behind the call to author novels based on Islamic identity. The induction of Islamic fiction into the world's literature scene is not merely a late twentiethcentury or early twenty-first century novelty. Rather, the claim that fiction and theology can feed into each other's significance and reach, dates far back in history. A twentieth-century British writer of renown, T. S. Eliot in an essay entitled Religion and Literature, frowns upon any definite separation between religion and literature, and champions, instead, a completion of literary criticism by criticism from an ethical and theological standpoint (150). According to her, there is more to the value of literature than its literariness: "The "greatness" of literature cannot be determined solely by literary standards' (150). While admitting to the tacit surmise amongst his contemporaries that "there is no relation between literature and theology", Eliot warns that "this is not to deny that literature", viz., notably works of fiction "has been, is, and probably will always be judged by some moral standards" (150). Hence the necessity of carefully examining "reading, especially of works of imagination, with explicit ethical and theological standards" (150). Eliot's concern is not so much with religious literature but with the unavoidability of reading literature though religious lens.

Leila Aboulela's debut novel, The Translator, makes, in no small measure, a riveting read. Set in Aberdeen and Khartoum, the story revolves around the life of a young female Arab translator of Sudanese extraction, gone by the name of Sammar. She was born in Britain. A few years after losing her hubby to a tragic accident, Sammar gets acquainted with a Scottish academic, Rae Isles, "a MiddleEast historian and lecturer in Third World Politics" (5). The chemistry between the two is right from their first meeting. Sammar works in Rae's department as a translator of Arabic into English. Thanks to his strong character and humanness Rae becomes a shoulder to cry on for Sammar who has her way cut out coming to terms with the psychological fallout from Tariq's passing. As time goes by, the complicity between the two grows into love. Sammar and Rae are so entangled emotionally and intellectually that neither can brook the physical absence of the other for long. The rub to the materialization of Sammar's stubborn desire to get married to Rae finds expression in the yawning cultural and religious divide between them. If anything, Sammar is a person of faith whilst Rae is agnostic. Even though she is head over heels in love with Rae to the point of catering for him (especially during his asthma bouts), Sammar draws the line at flouting Sharia law and espousing him. Deeply religious, she goes out of her way to convince Rae to convert to Islam, pleading with him to say the Shahada, so their union can take place. But Rae is having none of it on philosophical grounds. Disappointed to the core, Sammarretuns to Sudan, only to be faced with another psychological ordeal: her aunt Mahasen (Tariq's mother) fathers the blame of her son's death on her and, consequently, makes mischief for her every step of the way. The memory of Rae haunts Sammar in the form of dreams. Sammar's woes find a happy ending as Rae eventually makes a trip to Sudan, and converts from agnosticism to Islam, thereby paving the way for their marriage.

Rae and Sammar are two persons thrown together by a sheer quirk of fate. But a close scrutiny of their mindsets reveals that they united in a common drive to make diversity an asset in human relationships as against a poison. Rae's openness and intimate knowledge of the Arab world is a mirror image of Sammar's grim determination to thoroughly live out her Muslim faith while reaching across the religious and racial aisles to display tolerance and acceptance of diversity. Actually, Sammar's relationship with Rae serves as a potent reminder of the moral and ethical nothingness of barriers of any ilk. Four years into the gruesome untimely death of Tariq, Sammar crosses Rae's path. This chance encounter coupled with the subsequent romantic entanglement turns out to be Sammar's road to Damascus. Witness the refreshingly soothing words that Rae has for Sammar when she drops by his office after a gruelingly hectic 
working day: "I always have time for you, I can't bear anyone else at this moment except you" (35). As a Muslim immigrant, Sammar is made to feel like an outsider and, consequently, struggles to fit in. She registers her sense of culture shock in her fear of speaking out of turn: "In this country, when she spoke to people, they seemed wary, on their guard as if any minute now she would say something out of place, embarrassing" (6). Rae is something of a ray of sunshine for Sammar. The latter is in debt to the former for enabling her at times to get off the hook of the unflattering status of an "alien". Much as the memory of Tariq haunts her every step of the way, she, nonetheless, sees in Rae an opportunity to find some form of closure. Rae passes himself off as a knight in shining armour for the widowed Sudanese: "He said he wanted to take her to places where she would forget and remember" (57). The romantic relationship that plays out between them against a background of immigration speaks to the author's perception of love as a bridge across cultures. Also, it bespeaks a no-nonsense pushback against a race-tinged misrepresentation of Islam as well as a dogged move to cut across racial and cultural boundaries with an eye towards an erasure of the trope of cultural homogeneity. As if to lend credence to Aboulela's redemptive project in The Translator, Sadia Abbas contends that "The West's antipathy to Islam is an emanation from an aphorism that religion is the opiate of the people" (453). She goes on to posit that the "heroine's desire for masculine tenderness becomes a partial allegory for what is explicitly stated- a psychological need for social peace" (452). The meeting of mind between the Sudanese and the Scot is akin to what John Welwood calls "soul connection" as opposed to "heart connection" upon which phrases he elaborates as follows:

A soul connection is a resonance between two people who respond to the essential beauty of each other's individual natures, behind their facades, and who connect on a deeper level. This kind of mutual recognition provides the catalyst for a potent alchemy. It is a sacred alliance whose purpose is to help both partners discover their deepest potentials. While a heart connection lets us appreciate those we love as they are, a soul connection opens up a further dimensionseeing and loving them for who they could be, and for who we could become under their influence. (Qtd. in Hooks 182) ${ }^{2}$

${ }^{2}$ This E-edition is not numbered.

ISSN: 2456-7620
The politics of love in The Translator foregrounds a praxis embedded in openness and understanding. In the estimation of nineteenth-century American theologian and philosopher, Paul Tillick, listening goes with the territory of falling in love: "We cannot learn to communicate deeply until we learn to listen to each other but also to ourselves and God. Devotional silence is a powerful tool, for the healing of a heart or the healing of a nation" (Qtd. in Hooks 157). Sammar exemplifies this point big time in her numerous one-on-ones with Rae during which she strives flat out to gauge Rae's frame of reference with a view to seeing if they are cut out for each other. It turns out that Rae knows a thing or two about Arab affairs, which has really blown Sammar away. Despite being of Arab stock, Sammar got briefed about several facets of the Arab world thanks to her Scottish boss. More to the point, Rae, much to Sammar's amazement, is not cast in the mould of those Westerners whose stock-in-trade is their obnoxious antiMuslim and Arab rhetoric. Many a time Rae has had to face the music of his iconoclastic stance. Rae provides Sammar with Giddens calls "ontological security", upon which he expands as follows:

The phrase refers to the confidence that
most human beings have in the continuity of
their self-identity and in the constancy of the
surrounding social and material
environments of action. A sense of the
reliability of persons and things, so central
to the notion of trust, is basic to the notion of
ontological security. (92)

Indeed, Rae was able to overcome Sammar's reluctance to trust him thanks to his strength of character and animus against exclusion and marginalization. Sammar is well aware that Rae is looked on as " a traitor to the West", namely "the idea that the West is best" (22). The crux of the matter is that Rae is a knocker to a conception of identity that feeds on the trope of race, and intolerance. His expulsion from school for writing an essay provocatively entitled Islam is better than Christianity (Aboulela 17) says a mouthful. A jaw-dropping broadmindedness coupled with an empathetic fiber makes it possible for the pundit on Middle-East affairs to strike a chord with Sammar. These qualities allow him to reach out to the 'other', to wit, the 'alien', the 'outsider' epitomized by his Sudanese translator. The Sudanese woman's view of the Scot as "sort of familiar, like people back from" (21) speaks volumes about the feeling of kinship between them and, more significantly, the possibility of bridging the cultural divide with an eye towards forging a rock-solid bonding relationship. The absence of parochialism in Rae's worldview factors hugely into what endears him to 
Sammar, whose heartfelt shout-out to the Middle-East historian is a study in gratitude:

From the beginning she had though that he
was not one of them, not modern like them,
not impatient like them. He talked to her as
if she had not lost anything, as if she were
the same Sammar of a past time. Talked to
her in that way not once, not twice, but every
time. So that she had been tempted to ask, in
the moments when the mind loops and ebbs,
where do you know me from, why are you so
different from everyone else. (34)

The portrayals of these high-profile characters enact an authorial perspective about identity that extols the commonality of human beings. Sammar, as a sounding board of Leila Aboulela, resists being positioned as backward-looking owing to her faith, whereas Rae pushes back with the utmost energy on a Western narrative respecting identity, the hallmark of which is cultural supremacy. Little wonder that, from Sammar's vantage point, Rae is a marked man: "He's got enough critics as it is: those who think that he is too liberal, those who would even accuse him of being a traitor just by telling the truth about another culture" (22). Plainly, claims of racial and cultural purity encapsulate a disdain of difference, and, accordingly, feed on the dung of 'othering' significant chunks of humankind. Islamic fiction offers a counter narrative that flags up the humanness of Islam, and debunks the notion of Muslim faith being incompatible with modernity. The rationale for this thinking lies in a dogged determination to foreground the primacy and complete centrality of the west (Said 22). Edward Said castigates this frame of mind due to "how totalizing is its forms, how all-enveloping its attitudes and gestures, how much it shuts out even as it includes, compresses, and consolidates" (22). Both Sammar and Rae have a thing about "theories of essentialism and exclusiveness" the difficulty with which, Edward Said says, "is that they give rise to polarizations that absolve and forgive ignorance and demagogy more than they enable knowledge" (31). The racist overtones embodied in 'theories of essentialism and exclusiveness' turn Sammar off as they served as a staple diet for orientalists during the colonial era. The sheer evocation of "Orientalists" conjures up in her searing memories: "Orientalists were bad people who distorted the image of the Arabs and Islam. Some from school history or literature, she could not remember. Maybe modern orientalists were different" (21). The fag end of the quotation is a broad hint that Sammar is well-disposed to Rae.
That Sammar loves Rae and wants him to date her is a no-brainer. Much of her agency revolves around ways and means of realizing her dream: walking down the aisles with the Scottish academic. But she knows only too well that no end of treacherous potholes dot the road to her dream coming true. She acknowledges that differences in religious and social backgrounds stand as a huge stumbling block, and potentially portend failure: "Sammar felt separate from him, exiled while he was in his homeland, fasting while he was eating turkey and drinking wine. They lived in worlds divided by simple facts-religion, country of origin, race-data that fills forms" (34). Although a big hurdle is removed, namely her awareness that he is on the wagon, the fact remains that their marriage is still a long way off. Notwithstanding, Sammar cannot emphasize enough how significant Rae's decision to forego alcohol is, for it might shorten the odds on their union: “...he doesn't drink anymore [...] He had told her that and it had been another thing which made him less threatening. Another thing which made him not so different from her" (34). Sammar's sigh of relief upon discovering that Rae is a teetotaler is not only faith-informed with regards to the prohibition of alcohol under Sharia law but it also carries a hope that things might eventually pan out well.

With Rae at hand, Sammar is able to pick up the thread of her life and move on. Assuredly, he has given her a new lease in life. As she goes to great lengths to ingratiate herself with Rae, she makes it a point of wearing her heart on the sleeve of her ethnic and religious backgrounds. Sammar does not wallow in self-consciousness. Anytime that prayer time finds her in Rae's house, she makes no bones about taking leave of him for a while just to say her prayers before coming back. The gravitas and truthfulness of her everyday agency partakes of the aesthetic of 'Halal' writing whose distinctive feature is, arguably, the promotion of Islamic morality and ethics in human relationships. The rejection of religious hypocrisy is decidedly inscribed in Aboulela's portrayal of Sammar, whose mien throughout the narrative is a reproach to partial for worldliness at the same time that it fosters humility. Abdullah R. Muhametov and Laila-Olga provide insight into the religious purport of temperance and humility:

The values of modesty and genuine humility are God-given, and those who possess those characteristics are blessed indeed. Moreover, they are lights shining in the darkness, giving an example and goodness to others.

A truly modest person makes the raucous pomposity and arrogance of others to show; 
a truly-living person makes nonsense of the ephemeral wealth-and-status seeking ambitions of those who do not realize there is more life than just this level of existence. (Part 4, 5.1.)

Sammar relentlessly strives to negotiate her woes thanks to a remarkable self-possession anchored in faith. For instance, when her much beloved husband died in a most unexpected and tragic way, she, albeit bereaved to the core, refused to wallow in despair. "Only Allah is eternal, only Allah is eternal,' (9) she says resignedly as she is busy collecting Tariq's useful memorabilia like "photographs, books, towels, sheets" while thinking about taking to the mosque "a pair of shoes, Tariq's coat, he little rug" in case someone should need them. All this comes against the background of the preparations for the flight back home to Khartoum where her deceased hubby is to be buried in accordance with Islamic tradition. So faith-driven agency is what makes Sammar tick. She is, in no small measure, the mirror image of Rae in terms of worldview. Sammar may be of Sudanese stock and, to boot, an immigrant, yet she feels a sense of belonging in her land of adoption. While steadfastly keeping up what marks her off from native Brits-her Muslim identity-, she displays openness and tolerance towards non-Muslims. By the same token, Rae, albeit a native Brit and a secularist into the bargain, doggedly pushes back against hegemonic race-tinged versions of identity construction. Rae's humanistic bend shines through his searing critique of any claims of purity and homogeneity regarding culture. Arguably, both embody the human face of identity construction. Jeffrey Weeks's perspective on identity captures the meaning of the meeting of mind between the Sudanese and her Scottish boss:

Identity is about belonging, about what you have in common with some people and what differentiates you from others. As its most basic, it gives you a sense of personal location, the stable core to your individuality. But it is also about social relationship, your complex involvement with others, and in the modern world these have become more and more complex...At the centre, however, are the values we share or wish to share with others. (88)

Unsurprisingly, Sammar's view of dating is faithinformed. Hence her strenuous drive to learn more about Rae. The latter, being the soul of honesty, sees to it that his past and present are an open book to her. Similarly, the
Sudanese woman comes clean about any facet of her past life. No skeletons in the cupboard of theirs are kept under wraps. A case in point is Rae's disclosure to Sammar that he is a divorcé with one daughter from his previous marriage, named Mahairi. Rae errs on the side of earnestness when he brazenly spins a yarn about the affronts that he has swallowed from his first wife:

At night...quarrels... I used to feel such
peace when I went to work, talked to
students in the morning, soothed myself with
a lecture on Foreign Policy Analysis. I
stayed late, avoided going home. And the
later I went, the later the quarrelling started,
the later it went on through the night. Sleep
deprivation is torture. (40)

Another example of Rae's no-nonsense call to make his past life an open book to Sammar appertains to his Uncle David's fallout with his mother after failing to return home from a tour of duty in Egypt during the Second World War. What, indeed, sticks to Rae's mother's craw is David's willful resignation from the army and subsequent conversion to Islam. David's change of faith may be a shock to the system for Rae's mother-whose name is not by the way mentioned at any moment throughout the story-, but it fuels Sammar's hope that the Scot will someday follow suit. It's noteworthy, though, that Sammar does not feel up to providing a clear-cut answer to Yasmin's oft-asked question "Are you hoping he would convert so you could marry him?" At bottom, a thick wall of religious barrier separates Sammar from Rae which risks scuppering any marital project. Indeed, Islam proscribes marriage between a Muslim woman and nonMuslim man. Hence Sammar's all-out drive to have Rae saying what she calls the shahadah upon whose purport Swiss acclaimed academic, Tariq Ramadan, elaborates as follows:

...we might fairly, I believe, consider the notion of shahada $^{3}$ (testimony) insofar as it takes two important forms. The first goes back to the shahada that every Muslim, in order to be recognized as such, must pronounce before God and the whole of humankind, and by which he establishes his identity: "there is no god but God and Muhammad is His messenger." The second is connected with the responsibility of Muslims according to the Qur'anic injunction, to "bear witness [to their faith]

${ }^{3}$ Shahada and tawhid are italicized in the book; it is I who underline. 
before humankind." In the idea of shahada, testimony, we bring together essential elements of the Muslim faith: a clear remembrance of the fundamental core of our identity via faith in the oneness of God (tawhid) and his last revelation to the Prophet Muhammad... (74-5)

In light of the foregoing, it's not hard to understand why so God-fearing a woman like Sammar is unyielding in her demand that Rae say the shahada as a prerequisite for them getting married. The ethics of courtship and marriage under Islamic law rest on a rock-solid fidelity to an identity marker: faith. Decades of living in Great Britain has not dented in any shape or form Sammar's adherence to the teachings of Islam. This doubtless accounts for her adamant but subtle refusal of any physical intimacy with Rae, however much she loves him: "He left his desk and came to sit with her, leaned to kiss her but she moved her head away. His chin brushed against her scarf. They laughed a little, embarrassed now, a nervous laugh like breathing" (124). As she prepares to fly to Egypt on an anti-terrorist project mission, she cannot help but take the plunge and plead with Rae to say the shahada:

\begin{abstract}
She said, 'I wanted to talk to you about the shahada, what it means.' She breathed in and went on, 'It's two things together, both beginning with the words, "I bear witness". I bear witness, I testify, to something that is intangible, invisible, but I have knowledge of it in my heart. There is no god, except Allah, nothing else is worthy of worship. That's the first thing... Then the second thing . . I I bear witness that Muhammad is His messenger, a messenger not only to the Arabs who saw him and heard him, but to everyone, in every time.' (123)
\end{abstract}

In the same breath, Sammar presses her argument home by launching into an exegesis about the significance of messengers in Islam, emphasizing that "every messenger comes with proof about himself, a miracle suitable to his time" (123). The dividing line between Muhammad and the prophets who preexisted him (Moses, Jesus and others) is the Qur'an, viz., the miracle that was sent with him (124). The circle that Sammar tries to square is a tall order, Rae being of the kind who does not take a shine to religion. His submission that "it's not in me to be religious", in reply to Sammar's beseeching him to recite the shahada, betokens a mindset anchored in liberal secular values the hallmark of which has it that "it be kept separate from politics, law, and science-spaces in which varieties of power and reason articulate our distinctively ISSN: 2456-7620 modern life" (Talal Assad 29). Rae's agnostic bend further shines through his cast-iron substantiation of his reluctance to go religious:

I studied Islam for the politics of the Middle East. I did not study it for the sake of myself. I was not searching for something spiritual. Some people do. I had a friend who went to India and became a Buddhist. But I was not like that. I believed the best I could do, what I owed a place and people who had deep meaning for me was to be objective and detached. (126)

Strangely enough, here, Rae stresses the importance of religion as a recipe for a better understanding of the world. In Human All-too-Human, high-profile nineteenth-century German thinker, Friedrich Nietzsche, writes that in the era of rationalism "justice was not done to the importance of religion" despite the fact that it "was treated lovingly" and "a deeper, even the very deepest, understanding of the world was ascribed to them" (113). Secularists' animus for religious matters may stem from the strictures that go with the territory of faith. Faith has many claims on the believer. Once you embrace a religion, your mind is turned towards the achievement of something which sophisticated theologian Paul Tillich calls "ultimate concern": "Faith as ultimate concern is an act of the total personality. It happens in the center of the personal life and includes all its elements. Faith is the most centred act of the human mind" (15). Faith is crucial to the dynamics of personal life (Tillich 15). On that score, it resists, so to speak, being belittled. A person of faith always balks at any attempt to disparage religion as it is tantamount to making a mockery of that which forms the core of their being. Little wonder that Sammar felt slighted big time when Rae offhandedly served notice that conversion to Islam was a non-starter for him. She construes Rae's point blank refusal to turn religious as unrequited love and, not surprisingly, wallows in self-deprecation: "She though, it is clear now, it is so clear, he does not love me enough, I am nor beautiful enough. I am not feminine enough coming here to ask him to marry me when I should have waited to be asked" (128). Unsurprisingly, the poignancy of Rae's comeback has thrown Sammar for a loop since, from her vantage point, her huge emotional investment in the Scot has come to grief. Just like that she goes berserk: "Why did you talk to me then? From the beginning, why did you start all this. You should have just left me alone. You had no right, if you were content in your religion..." (128). Rae's reply that "I'm not content, there are many things I can't justify to myself" did nothing to assuage Sammar's attachment 
injury": "I wish I never trusted you" (128). As stated above, Sammar is coming up short due to her inability to successfully gear her attachment bonds with Rae towards the end game that she craves for so much-that is, marriage. Faced with Rae's hard line stance on the shahada, Sammar grows to develop low self-regard, and other "reactive attitudes" bordering on hissy fits: "I'm going to pray that if it's not me then it's no one else and you can live the rest of your life alone and miserable. There really must be something wrong with you to have been divorced twice, not once, but twice" (129). Rae's command "Get out of here", "Get away from me" means splitsville for the two. Furthermore, the disappointingly nasty twist in the love saga between Sammar and Rae buttresses TadejTroha's contention that "choosing to love always means choosing to hate as well, and the entire spectacle of love only serves to conceal the failure of keeping both impulses apart" (223). Hate just lies beneath the surface of love. Attachment injury can occur anytime in couple relationships or in romantic relationships, leaving partners falling apart at the seams. Sophisticated nineteenth-century German philosopher, Arthur Schopenhauer's construction of love "as a malevolent demon, striving to pervert, to confuse, and overthrow everything" (534) shines through Sammar's mien after her return to Sudan. If anything, she is hard pressed to get Rae off her mind despite the excruciatingly painful circumstances under which they

\footnotetext{
${ }^{4}$ Attachment injury is a key component of attachment theory. Susan M. Johnson et al. defines it as "any incident where an individual partner is perceived to be inaccessible or unresponsive in a critical moment, especially when attachment needs are particularly salient. This is significant because it results in a tear in the fabric of, disconnection in, the attachment bond creating negative interactional cycles that perpetuate relational distress" (Johnson et. al 56). Although Sammar and Rae are not in a couple relationship as such, the fact remains that there is an affectional bond between them that manifests itself several times during the narrative. They provided assistance and succor to each other in each other's hour of need. Actually, Sammar left no stone unturned to nurse Rae back to health from a bout of asthma, going regularly to the hospital to visit him; the Scot paid her in kind by, inter alia, defraying the cost of her acquisition of a suitable driving license. Sammar cannot brook the absence of Rae for too long. Nor can Rae put up with the privation of Sammar's sight for a long period of time. When the Scottish historian breaks to the translator that his Egypt-based uncle David has passed away and that he is going away to attend the funeral, she says: "I wish I could come with you" (113). Rae's reply "I wish you could, it would make all the difference" is a measure of his heartache of having to take leave of her, even if only for a couple of days. Frequent phone conversations allowed them to catch on each other's news, which contributed no end to shore up their relational bond. Understandably, Sammar experiences Rae's call not to convert as an attachment injury, the unexpectedness and poignancy of which has made her shake the dust of Scotland off her feet. She feels like it galls her to continue living in the same land with Rae after their spat.
}

ISSN: 2456-7620 reached the end of the road and, consequently, went their separate ways. Rae continues to haunts Sammar in baffling dreams:

But she dreamt of him. Dreams in which he dreamt past her, would not look at her, would not speak to her. Dreams in which he was busy talking to others. When she thought his attention he frowned and it was a cold look that she received, no fondness. She would wake after such dreams with raw eyes, mumbling and clumsy, dropping things, mislaying things. When asked what was wrong with her, she would say that it was the time of month. (163)

The prime mover of psychoanalysis, Sigmund Freud, views the dream "as the psychic life during sleep" (73). Speaking of sleep itself, Feud feels that "it is a condition in which I wish tohave nothing to do with the external world, and have withdrawn my interest from it" (73). The fact that the dream is "a neurotic symptom" implies a mental condition whose examination can provide cogent sidelights into the psyche of the dreamer: "Dreams are often senseless, blurred, absurd; but there are some that are meaningful, sober, sensible" (Feud 81). Harking back to Sammar's dream in the foregoing quotation, the case can be made foursquare that the manifest content of the dream, viz., "that which the dream relates" is Rae. By the same token, the latent dream thoughts, namely "that which is hidden, which we can only reach by the analysis of ideas" (Freud 87), also points to Rae; so, the Middle-East historian's absence in the Sudanese translator's life weighs heavily on her. The cold shoulder that Rae gives Sammar in the dream can be traced to the pained circumstances of their separation, underscoring her inability to draw a line under the past. The dream being the manifestation of a "wish fulfilment", it can be argued that Rae's sight in Sammar's hallucinatory experience is cold comfort for her. Dreaming about an old flame is not devoid of meaning altogether. Rather, it doubtless registers a sentiment the significance of which varies depending upon the interpretation made of it. In the case of Sammar, the happy memories of her life with Rae back in Scotland still sit with her at the same time that the parting of ways with the Scot still rankles.

Sammar's preference of the hellhole that Sudan represents (with the recurrent power outages, and dust-ups with Aunt Mahassen) to a hunky-dory stay in Aberdeen, bears testimony. Her brother Waleed's jaw dropped on seeing her back home in Khartoum. Dismayed at what he regards as his sister's ill-advised choice to shake the dust of Scotland off her feet, he constants exhorts her to "go back 
to England, work there, and send us things" (169). Sammar isn't having any of it, though: "I don't want to go back." Her flat refusal to toe her brother's line may sound gruff at first glance. However, it has a feminist edge to it. More significantly perhaps, a leap into Sammar's psychology reveals an obdurate concern not to be seen as kowtowing to Rae, probably out of womanly vainglory. Deep down, she feels that going back to Scotland as if nothing happened won't make any difference, Rae being dug in. Quite unexpectedly, the pundit on Middle-Eastern affairs eventually converts to Islam, and flies to Khartoum with an eye to popping the question to Sammar. FareedKhalifa, a friend of Rae's and a journalist by trade who "was imprisoned by the Israelis", has just sent a letter to Sammar, telling her about the good tiding. Interestingly, the about-face of Rae vindicates Sammar's forbearance as a person of faith; she puts a religious spin on it: "...she was being honoured now, she was being rewarded. All alone, a miracle for no one else to acknowledge but her. The sky had parted, a little crack, and something had pierced her life" (187). Rae's conversion is, in many regards, a deuxeksmakina. This echoes SadiaAbass' metaphorical take on the happy twist in the relationship between the two protagonists of the novel: "Their union is like the divine sleight of (invisible) hand that replaces Ismail with a lamb because Abraham and Ismail had already consented to the imminent slaughter and accepted it as a duty. Romance, confession, conversion, and providence-neatly wrapped up" (438). The cogency of religious conversion and the redemptive significance of female dignity are glowingly inscribed in the ultimate mediation of the marital bond between Sammar and Rae isles

When all is said and done, The Translator is doubtless a masterpiece that foregrounds the significance of faith in navigating the intricacy of inter-human relationships, and life's twists and turns. The authenticity of the novel lies in its rebuttal of a western construction of integration as acculturation and assimilation. This is a perspective that accounts for the fractiousness of the relations between immigrants of Islamic tradition and host societies of Judeo-Christian bend. The authorial proposition that differences in faith and ethnic origins ought not to be a recipe for hate shines through the castings of Sammar and Rae Isles. Halal fiction extols human respect and dignity as it foregrounds faith as a praxis of life geared towards across the board moral uplifting. The aforementioned praxis has a bearing upon the politics of courtship, not least between a Muslim woman and a non-Muslim man. Also, Leila Aboulela's novel is a study in the merits of faith as well as an indictment of the erection of racial and ethnic boundaries for the sake of cultural purity.

\section{REFERENCES}

[1] Arifa, Akbar. "Back to Khartoum: Leila Aboulela Returns to the Land of Her Fathers." The Independent, 17 December, 2010. Retrieved from http//www.independent.co.uk/artsentertainment/books/features/back-to-khartoum-leila-aboulelareturns-to-the-land-her-fathers-2162261.html, Accessed 20 July 2020

[2] Abass, Sadia. "Leila Aboulela, Religion and the Challenge of the Novel" in Contemporary Literature, 52, 3 (2011) pp.430460.

[3] Assad, Talal. Formations of the Secular: Christianity, Islam, Modernity. Stanford, California: Standford University Press, 2003.

[4] - Genealogies of Religions: Discipline and Reasons of Power in Christianity and Islam. Baltimore, Maryland: The Johns Hopkins University, 1993.

[5] Aboulela, Leila. The Translator. New York: Black Cat, 1999.

[6] Church, F. Forrester. (Ed.),The Essential Tillich: An Anthology of the Writings of Paul Tillich. Chicago: The University of Chicago Press, 1999.

[7] Cliteur, Paul. Secular Outlook: In Defense of Moral and Political Secularism. Oxford, London: Wiley-Blackwell, 2010.

[8] Giddens, Anthony. The Consequences of Modernity. Cambridge, London: Polity Press, 1990.

[9] Jones Sr., Michael L. Conflict En Route to Destiny. Victoria, Canada: Trafford Publishing, 2010.

[10] Khan, Mohd Imran, Haleem, Abid. 'Understanding "halal" and "Halal Certification \& Accreditation System"-A Brief Review' in Saudi Journal of Business and Management Services, Vol-1, Iss-1 (Feb-Apr, 2016): 32-42

[11] Hooks, Bell. All about Love. New York: HapperCollins Publishers, 2001.

[12] Nash, Geoffrey. Writing Muslim Identity: The Construction of identity. London: Continuum International Publishing Group, 2012.

[13] Nietzsche, Friedrich. Human All-Too-Human: A Book for Spirits. [Trans. Helen Zimmern with introduction by J. M. Kennedy]. Edinburg and London: T. N. Foulis, 1910.

[14] Nussbaum, Martha C. Cultivating Humanity: A Classical Defense of Reform in Liberal Education. Cambridge, Massachussets: Harvard University Press, 1998.

[15] Ramadan, Tariq. Western Muslims and the Future of Islam. Oxford and New York: Oxford University Press, 2004.

[16] Rolley, John A. G. A basic and Scriptural study on Faith! Victoria, Australia: Traillblazer Ministries, 2012.

[17] Said, Edward W. Culture and Imperialism. New York: Vintage Books, 1994.

[18] Schopenhauer, Arthur. The World as Will and Representation. Volume II. Indian Hills, Colorado: Falcon's Wings Press, 1958.

[19] Weeks, Jeffrey. The Value of Difference. In J. Rutherford (Ed.), Identity: Community, Culture, Difference (pp. 88-100). London: Lawrence and Wishart, 1990. 